\title{
Volume 4 Number 3
}

Journal of

Child Language

\section{Cambridge University Press}




\section{Reading Committee}

C. Cazden (Harvard), S. Ervin-Tripp (Berkeley), C. Ferguson (Stanford),

Y. Lebrun (Brussels), P. Menyuk (Boston), E. Oksaar (Hamburg),

T. Slama-Cazacu (Bucharest), D. Slobin (Berkeley),

N. Stemmer (Bar-Ilan, Israel).

\section{Advisory Board}

E. O. Apronti (Ghana), U. Bellugi (Salk Institute), B. Bernstein (London), M. Braine (New York), R. Brown (Harvard), M. Bullowa (M.I.T.),

E. Clark (Stanford), M. Donaldson (Edinburgh), W. Kaper (Amsterdam),

A. R. Kelkar (Poona), D. McNeill (Chicago), M. Mikes (Novi Sad), D. Parisi (Rome), J. Prùcha (Prague), W. Von Raffler Engel (Nashville), V. Rũke-Dravina (Stockholm), I. M. Schlesinger (Jerusalem), H. Sinclair (Geneva), I. Spilka (Montreal), A. W. Staats (Honolulu), the Secretary of the International Association for the Study of Child Language.

\section{EDITORI AL POLI CY}

The journal publishes material on all aspects of the scientific study of language behaviour in children and the principles which underlie it. This includes both normal and pathological development, and the study of both monolingual and muitilinguai chiddren. Articies may report findings from naturalistic observation, experimental techniques, therapy or educational settings; and the subject-matter may include sounds, grammar, lexicon, semantics, dialect variation, language use, or any other recognised facet of language study. Articles may be limited to the investigation of one language, or they may be comparative studies; focused on individuals, or presenting statistical treatments of groups. Studies of reading, writing, and the use of sign language are included if they are related to general questions of language development; as are articles with a therapy or remedial education bias. Collections of data are acceptable if they are accompanied by adequate interpretive discussion. (Notes for contributors are given on the inside back cover.)

\section{(C) Cambridge University Press 1977}

\section{PERMISSIONS}

For permission to reproduce material from Yournal of Child Language, please apply to the London or New York office of Cambridge University Press.

ISI Tear Service, 327 Chestnut Street, Philadelphia, Pennsylvania 19106, U.S.A. is authorized to supply single copies of separate articles for private use only.

\section{SUBSCRIPTIONS}

Fournal of Child Language is published three times a year, in February, June and October; three parts form a volume. The subscription price of Volume 4,1977 , is $£_{14} .00$ net (US $\$ 36.00$ in the USA and Canada) for institutions, $£_{9} .00$ net (US $\$ 25.00$ ) for individuals, including postage. Single parts cost $£ 6.00$ each (US $\$ 15.00$ in the USA and Canada), plus postage. Orders should be sent to a bookseller or subscription agent or direct to Cambridge University Press, Bentley House, 200 Euston Road, London NWI 2DB (in the USA and Canada, to Cambridge University Press, 32 East 57th Street, New York, N.Y.I0022). Copies of the Journal for subscribers in the USA and Canada are sent by air to New York to arrive with minimum delay. Claims for missing issues should be made immediately after receipt of the subsequent issue of the Journal.

\section{ADVERTISING}

Enquiries about advertising in the Journal should be sent to the publishers. 